\title{
Consequentialist Reasons for Some Education Reforms
}

ZDENKO KODELJA ${ }^{1}$

$\approx$ The reasons for education reforms - as a particular form of social reforms - are either consequentialist or non-consequentialist. However, the reasons for the education reforms that are briefly discussed from the perspective of the philosophy of education in the present paper are above all consequentialist. These are the reasons for proposed education reforms in EU countries whose strategic aim is equated with the enhancement of two values: creativity and innovation. It is supposed that these education reforms will have good effects and not that they are good in and of themselves. Therefore, although creativity and innovation might be seen as having intrinsic value, they are - in these education reforms - treated predominantly as instrumental values. It seems that the introduction of such education reforms can be understood as a decision founded not on causal explanation, but rather on the basis of a special type of teleological explanation, which has the logical form of a "practical syllogism". In this case, the occurrence of an action is explained in terms of the goals and purposes of the agent; it shows that the agent did what s/he did because s/he tried to achieve a certain goal and believed that certain means were necessary or sufficient for achieving this goal.

Keywords: education reforms, aims, instrumental values, creativity, innovation 


\section{Konsekvencialistični razlogi za nekatere reforme izobraževanja}

ZDENKO KODELJA

$\propto$ Razlogi za reforme izobraževanja kot posebne oblike družbenih reform so konsekvencialistični ali nekonsekvencialistični. Razlogi za reformo izobraževanja, ki so na kratko obravnavani $\mathrm{v}$ tem prispevku $\mathrm{z}$ vidika filozofije vzgoje, so predvsem konsekvencialistični. To so razlogi za tiste predlagane reforme izobraževanja v državah EU, katerih strateški cilj je enačen s krepitvijo dveh vrednot: ustvarjalnosti in inovativnosti. Pri tem se predpostavlja, da bodo imele te reforme izobraževanja dobre učinke, ne pa to, da so že same po sebi nekaj dobrega. Čeprav se mogoče zdi, da imata ustvarjalnost in inovativnost intrinzično vrednost, pa se $\mathrm{v}$ teh reformah izobraževanja obravnavata predvsem kot instrumentalni vrednoti. Zdi se, da uvedbe takšnih reform izobraževanja ni mogoče razumeti kot posledice odločitve, ki temelji na vzročni razlagi, ampak prej kot odločitev, ki temelji na posebni teleološki razlagi, ki ima logično formo "praktičnega silogizma«. V tem primeru je neko dejanje pojasnjeno $\mathrm{z}$ vidika ciljev in namenov akterja; kaže, da je akter storil to, kar je storil, zato ker je poskušal doseči določen cilj in je verjel, da so določena sredstva nujna ali zadostna za dosego tega cilja.

Ključne besede: reforme izobraževanja, cilji, instrumentalne vrednote, ustvarjalnost, inovacije 


\section{Introduction}

Education reforms are a particular form of social reforms. According to Jon Elster, there are essentially two types of reasons for social reforms. Some are consequentialist, grounded in a belief that the reform will have good or desirable effects, while others are deontological, based on the conviction that the reform is a good thing in and of itself (Elster, 1987, p. 709). However, the reasons for some of the education reforms - or their constitutive elements - that I discuss briefly in this paper from the perspective of the philosophy of education are above all consequentialist. It is supposed that these education reforms in EU countries - one of whose strategic aims is equated with the enhancement of two values: creativity and innovation - will have good effects: improving "enterprise development and Europe's ability to compete internationally" (Council of Europe, 2009, p. 3), and not that they are good in and of themselves. Moreover, although it might seem that creativity and innovation have intrinsic value, they are - in these education reforms - treated predominantly as instrumental values. Therefore, even if such education reforms, which are only a means to achieve the desired goals, have good consequences, their value is mostly instrumental. However, there is no guarantee that the introduced reforms will achieve the desired goals, because reforms and goals are not necessarily in a causal relationship; reformers as decisionmakers can merely believe in such a connection when they decide to introduce such reforms. If this is so, then the introduction of such education reforms can be understood on the basis of a special type of teleological explanation, which has the logical form of a "practical syllogism". In this case, the decision to introduce education reforms is explained in terms of the goals and purposes of those who made the decision. This means that they did what they did because they tried to achieve a certain goal and believed that certain means were necessary or sufficient for achieving this goal. ${ }^{2}$ In the present paper, the education reforms are intended as a means to achieve two goals: "enhancement of creativity and innovation" in all students, on the one hand, and improving "enterprise development and Europe's ability to compete internationally", on the other. However, the means proposed in EU documents (such as changes in curricula and teacher training) to achieve the first goal will not be discussed here. ${ }^{3}$

2 At this point, I leave aside the question of whether intention itself can be the cause of action, as causalists think, or whether the connection between intention and action is purely conceptual and logical in nature, as intentionalists think (Von Wright, 1971, pp. 39-53).

3 Among the means that are presumed to make it possible to achieve this goal ("enhancement of creativity and innovation" in all students) are, for instance, mentioned and discussed changes in: curricula, teacher training, pedagogy and assessment, use of ICT and digital media, educational culture and leadership (Cachia et al., 2010, pp. 9-11). 


\section{Creativity and innovation as instrumental values that constitute an important aim of one of the proposed education reforms in the $\mathrm{EU}$}

One of the strategic and, as such, most important aims of EU education policies since 2009 has been: "Enhancing creativity and innovation, including entrepreneurship, at all levels of education and training" (Council of Europe, 2009, p. 3). ${ }^{4}$ Since educational aims are understood as values that education should aim for, and since values are values just because they are something good or are thought to be good, ${ }^{5}$ it seems to be reasonable to conclude that enhancing creativity and innovation was declared as a strategic aim because creativity and innovation were seen as something so good that enhancing them deserves to be a strategic aim. The question is, however, whether they were chosen as one of the strategic aims because of their intrinsic or extrinsic value. For the purpose of the present paper, this is certainly a very important question. However, it might be seen as a problematic question as well. Why? Because it already presupposes that creativity and innovation can have intrinsic value. This presupposition is wrong in two cases: firstly, if there is not at all such a thing that has intrinsic value; and secondly, if only one thing, which is neither creativity nor innovation, can have such value.

Philosophers who have serious doubts about the idea of intrinsic value, or even reject it, belong to different philosophical traditions and use different arguments to justify their doubts and objections to the widely accepted theory that the intrinsic goodness of something is a genuine property of that thing.

4 Innovation and education were already considered as a means to achieve a key goal ("knowledge society") established by the EU in 2000, in the Lisbon Strategy. In 2009, the European Commission declared the "European Year of Creativity and Innovation" in order to promote creativity and innovation as key skills of all individuals "through formal and non-formal education". The main aim was "to create an environment that is conducive to all forms of creativity and innovation, whether artistic, cultural, social or technological, and to promote the practical use of knowledge and ideas" (EUR LEX, 2008). The Commission also stressed "the importance of encouraging creativity and innovation within education and training systems, which are themselves essential to the proper functioning of the knowledge triangle (education-research-innovation)". According to the Commission, that year "should lead to in-depth reflexion on the teaching methods and means of assessing learning achievements. Motivation and a sense of initiative at the heart of creativity and innovation should be further developed throughout the educational pathway of young and not-so-young people alike" (ibid.). Entrepreneurship, as defined in the EU documents, "refers to an individual's ability to turn ideas into action. It includes creativity, innovation and risk taking, as well as the ability to plan and manage projects in order to achieve objectives". As such, it is seen as a "key competence for growth, employment and personal fulfilment", which should be acquired throughout education from primary schools to university and lifelog learning (EUR LEX, 2006).

5 This claim seems to be justified at least in the context of philosophical theories of values that define them as "things that are good". William K. Frankena, for instance, says that utility values are "things that are good because of their usefulness for some purpose"; extrinsic values are "things that are good because they are means to what is good"; intrinsic values are "things that are good in themselves or good because of their own intrinsic properties", and so on (Frankena, 1973, ch. 5). 
"Especially well known for their dissent are Thomas Hobbes", "who believed the goodness or badness of something to be constituted by the desire or aversion that one may have regarding it, and David Hume," "who similarly took all ascriptions of value to involve projections of one's own sentiments onto whatever is said to have value" (Zimmerman, 2010). Later, similar arguments were used by the so-called "non-cognitivists". Among them we can find both emotivists and prescriptivists, who argue that there are no moral properties or moral facts and, therefore, that judgments about goodness and badness are not descriptive statements about the moral properties of a certain thing, but rather either expressions or evocations of feeling and attitude, or something that constitutes a kind of command as to how we are to act. This means that a claim that something is good is not a statement about that thing, which can be true or false, but an ascription of value to it, which can be neither true nor false, since it is an expression of feelings, attitudes, evaluations, recommendations or prescriptions. ${ }^{6}$

However, there are also other kinds of arguments that have been used for defending the idea that nothing has intrinsic value.? If we accept them, then it is obvious that the previously asked question - whether creativity and innovation were chosen as one of the strategic aims of EU education policies because of their intrinsic or extrinsic value - is illogical and nonsensical. The same could be said if the claim that only one thing can have intrinsic value were true, under the condition, of course, that for those who defend this claim, creativity or innovation is not such a thing.

According to Kant, for instance, the only thing that is intrinsically good or, in other words, good in itself, that is, good independently of its relation to other things, is a good will; Kant argues that the only thing "which can be regarded as good without qualification", that is, as unconditionally good, is "a good will". A good will is, therefore, good not because of its consequences, but "in itself" (Kant, 2004, pp. 63-64). ${ }^{8}$ This does not mean that other things cannot be good, but that they are not good in all circumstances, and "can also be extremely bad and hurtful when the will is not good" (Ibid., p. 63).

6 Referential authors are, for example, Charles L. Stevenson, among emotivists, and Richard M. Hare, among prescriptivists.

7 Monroe Beardsley, for instance, claims that all value is extrinsic and that nothing has intrinsic value (Beardsley, 1965, pp. 1-17).

8 Since only rational beings can have a good will, and good will is the only unconditional good, they have unconditional or, in other words, absolute value. As such, rational beings are an end in themselves and "not merely a means for arbitrary use by this or that will" (Kant, 2004, pp. 105-107). For this reason, they must treat one another as ends in themselves. In other words, just because they are ends in themselves, they "serve the will as a subjective ground of its self-determination" (Ibid., pp. 104-105). Since "the will is conceived as a power of determining oneself to action in accordance with the idea of certain laws", it follows that the law that determines the will is the categorical imperative formulated as: "Act in such a way that you always treat humanity, whether in your own person or in the person of any other, never simply as a means, but always at the same time as an end" (Ibid., pp. 106-17). 
Another theory according to which only one thing is intrinsically good is hedonism. Hedonism is usually interpreted as the ethical theory that defends the idea that "there is one thing, and one thing only, that is intrinsically good, namely pleasure" (Ross, 2002, p. 99). However, George E. Moore totally disagrees with such an interpretation. In his opinion, hedonistic utilitarianism "does not assert that pleasure is the only thing intrinsically good.... On the contrary, it asserts that any whole which contains an excess of pleasure over pain is intrinsically good" (Moore, 1912, p. 73). It seems that this interpretation of hedonism, as opposed to the first one, allows the conclusion that creativity and innovation, too, can have an intrinsic value if a whole - let us say a creative and innovative job - contains an excess of pleasure over pain.

In addition to this interpretation of hedonism, there is a variety of other philosophical theories that reject the idea that one and only one thing can be intrinsically good. In fact, these theories are widely accepted. As a result, there are different lists of things that are - or are supposed to be - intrinsically good, ${ }^{9}$ including creativeness (White, 1982, p. 9). Even if this is not a proof of their existence, it is at least proof that several philosophers argue that things that are intrinsically good exist. To discuss the arguments for and against their existence would exceed the purpose of this paper. The main purpose of this paper is to show that creativity and innovation in the context of EU education policies have instrumental value and that the very aim of education is not "enhancing creativity and innovation", but rather improving "enterprise development and Europe's ability to compete internationally" and "engendering personal fulfilment" (Council of Europe, 2009, p. 3). In order to justify this thesis, it is enough to quote the first part of the explanation of the aforementioned strategic aim, where it is stated: "As well as engendering personal fulfilment, creativity constitutes a prime source of innovation, which in turn is acknowledged as one of the key drivers of sustainable economic development. Creativity and innovation are crucial to enterprise development and to Europe's ability to compete internationally" (Ibid.). ${ }^{10}$

9 The most known is the following classical list of intrinsic goods: truth, goodness and beauty. One of the longest lists of intrinsic goods is that given by William Frankena, which includes: life, consciousness, and activity; health and strength; pleasures and satisfactions of all or certain kinds; happiness, beatitude, contentment, etc.; truth; knowledge and true opinions of various kinds, understanding, wisdom; beauty, harmony, proportion in objects contemplated; aesthetic experience; morally good dispositions or virtues; mutual affection, love, friendship, cooperation; just distribution of goods and evils; harmony and proportion in one's own life; power and experiences of achievement; self-expression; freedom; peace, security; adventure and novelty; and good reputation, honour, esteem, etc. (Frankena, 1973, pp. 87-88).

10 The fact that EU politicians understand and treat creativity and innovation as instrumental values is also evident in the explication of the Conference Theme of this ECER Conference: "National governments and the European Union see innovation as increasingly important for the development of the 21st century knowledge society. It may contribute to economic prosperity as well as to social and individual wellbeing and may, therefore, be an essential factor for creating a more competitive and dynamic European society. In the effort to manage the challenges facing societies and economies, political agencies and systems expect educational research, the social sciences and humanities to find solutions for developing creative and innovative education as a means to foster creative competences and innovative skills among the next generation" (Conference Theme, ECER 2013). 
What follows from this explanation is that in this context, both creativity and innovation have predominantly - if not only - instrumental value. This means that both are supposed to be something good not because of their intrinsic properties, but rather because they lead to other good things (Kant, 2004, p. 4): "personal fulfilment", "enterprise development, and to Europe's ability to compete internationally". Since creativity and innovation have a value only in virtue of being a means to an end, they are instrumental values. However, although they are both instrumental values, there is a difference between them: innovation, as a matter of fact, is an end to which creativity is a means. ${ }^{11}$ Despite this, both have instrumental values since innovation is not an end in itself, but rather a means to an end, which - in this case - is, as we have already seen, "enterprise development, and Europe's ability to compete internationally". Now, the question is whether this end is an end in itself or only a means to another end. This is an important question for two reasons. Firstly, if this end ("enterprise development and Europe's ability to compete internationally") is not something that is valuable for its own sake but for the sake of something else to which it is related as a means to another end, then innovation has instrumental value only if this other end (the one that is the final end in the given means-end relation) has intrinsic value. For, according to some interpretations, there can be no instrumental value without intrinsic value. Secondly, if the statement "innovation has instrumental value" means "innovation is conducive to something that has intrinsic value", then it follows that intrinsic value exists. ${ }^{12}$

Therefore, if things can have intrinsic value, then creativity and innovation can have it as well. Moreover, if they can have intrinsic value, then it would be possible that creativity and innovation were chosen as the strategic aim of EU education policies because of their intrinsic goodness. Since they were not or better to say, there is no evidence in the aforementioned EU documents that they were - it seems to me reasonable to conclude that they were intentionally chosen because of their instrumental value.

If this conclusion is correct, then the substantial part of the subtitle of this paper "Creativity and Innovation as Instrumental Values", can be understood in two different ways: as a statement of fact, which is either true or false, and as a value judgment, which is expressed as an implicit critique in the sense that creativity and innovation are treated only as instrumental values. Needless

11 Innovation is defined as "to introduce change in society and in the economy", and creativity as "to imagine something that did not exist before and to look for new solutions and forms" (Manifesto for Creativity and Innovation in Europe).

12 Beardsley rejects such interpretations and argues that the existence of at least one intrinsic value is not a necessary condition for the existence of instrumental values. In his view, what is necessary is to accept the following definition: " $\mathrm{X}$ has instrumental value" means " $\mathrm{X}$ is conducive to something that has value" (Beardsley, 1965, p. 64). 
to say, this kind of critique is only possible if there are intrinsic values and if creativity and innovation have intrinsic value. And the opposite: if those who deny either the existence of things that are intrinsically good or claim that only one thing can have intrinsic value are right, then such critiques are absurd. It would be illogical to criticize and blame EU politicians for treating creativity and innovation only as a means if they cannot be anything more than that.

On the other hand, it seems to me that this critique is in some way justified even if some philosophers are in considerable doubt about intrinsic values, since there is no sign at all that politicians in the EU treat creativity and innovation as means because they know or believe that intrinsic values are impossible, and they therefore treat them in the only possible way, that is, as a means. More plausible seems to be the assumption that they think that intrinsically valuable things exist, but, despite this, treat creativity and innovation as if they cannot have intrinsic value. And the opposite: some formulations in EU documents give the impression that they treat some other things, such as economic growth and the competitiveness of Europe, as if they were ends in themselves. Consequently, education, too, is treated by politicians primarily as a means of improving the economic situation in the EU, by helping to provide the kinds of workers that are equipped with the kind of competences that involve creativity and the ability for innovation. For this reason, it is perhaps worth repeating what Alasdair MacIntyre critically said in his famous article 'Against Utilitarianism' already half a century ago. He emphasised "that education should not aim only at instrumental goods - access to jobs, increased industrial production, increased consumption of goods and services, which in turn keeps up production, and so on", since a society and its education system that pursue "only means, without paying attention to any ultimate ends which these means might bring about", are irrational (MacIntyre, 1964, pp. 8-9; White, 1982, p. 14).

However, the question is not only whether creativity and innovation have - in the discussed EU document - predominantly intrinsic or instrumental value, but also whether enhancement of creativity and innovation - as a strategic aim of EU education policies - is in a causal relationship to "enterprise development and to Europe's ability to compete internationally", which seems to be the real goal of such education reforms. It is possible that reformers, that is, decisionmakers, only believe that creativity and innovation are in causal relation, and that their decision is based on the conclusion followed from the 
so-called "practical syllogism" or "practical inference", ${ }^{13}$ which has the logical form: (1) A wants B. (2) A believes that B will not occur unless he does C. (3) Therefore, A does C.

A practical syllogism is a teleological explanation that explains the occurrence of an action in terms of the goals and purposes of the agent; it shows that an agent did what he did because he tried to achieve a certain goal and believed that certain means were necessary and/or sufficient for achieving this goal.

In our case, the introduction of such an education reform can be explained in the following way: (1) Reformers would like to achieve the previously mentioned goals ("enterprise development and Europe's ability to compete internationally"); (2) Reformers believe that these goals will be achieved only if they themselves introduce the education reform (whose aim is: "Enhancing creativity and innovation, including entrepreneurship, at all levels of education and training"); (3) Therefore, reformers introduce such an education reform.

What should be stressed here is that we do not know whether the introduction of the education reform will enable the achievement of the intended goal, since, for the teleological explanation, it is not important at all whether the means (education reform) is in causal relation with the goal or not. The only thing that is important is that the reformers believe that the introduction of the education reform is necessary for achieving the intended goal. A similar understanding, that is, in accordance with the theory of practical syllogism, can be applied to the previously discussed education reform proposed by the EU and aimed at the enhancement of creativity and innovation, which is, in fact, a means to a further aim: "enterprise development and to Europe's ability to compete internationally". This seems to be the real aim of such education reforms.

Nonetheless, such teleological explanation does not solve one of the key problems related to the consequentialist arguments for social reform, which is, as Elster argues, that it is difficult "to assess before the fact what the consequences will be of a reform" (Elster, 1987, p. 710). Education reformers also face this problem: How can they know what the consequences of their decision will be? In fact, they cannot know in advance whether the consequences of introducing education reform will be better than they would have been if the reform

13 Von Wright explicitly links his theory of the practical syllogism to the work of Aristotle and also to that of Elizabeth Anscombe (von Wright 1971, pp. 26-27; cf. Anscombe, 1963). However, Anscombe (1989) claims that von Wright's so-called 'practical inference' is not practical at all. What von Wright calls 'practical inference' is a theoretical inference put to a practical use. The inference (I): $X$ intends $p$; $X$ believes that $p$ implies $q$; Therefore, $X$ intends $q$ is not a special form of inference. The only real logical inference involved in (I) is the purely theoretical inference (modus ponens): (MP) $p$; $p$ implies $q$ : Therefore $q$. An agent might put MP to practical use by reasoning from his intention to obtain $p$ to $q$ as the sufficient means, but this practical use of MP does not amount to a new form of inference (1989, p. 390). 
had not been introduced. Only after recalculating the positive and negative consequences can it be determined whether their decision was justified or not. Even then, a question remains: How can we know if they made the right decision if we need to know the consequences of their decision and compare them to the consequences that would have arisen if they had decided otherwise?

\section{Conclusion}

The discussion so far - which has been limited to treating creativity and innovation as instrumental values and at the same time as objectives of education reforms aimed at increasing the competitiveness of EU countries in the global market - needs to be understood in a broader framework of neoliberal policies. In this neoliberal context, which was also characteristic of EU policies at the time, education is not seen only as a precondition for developing creativity and innovation, but also as a key element of the nation state's ability to improve or maintain economic prosperity. Furthermore, the need for education reforms is, in the neoliberal context, mainly justified by economic reasons, especially the need to provide a more educated and more creative, innovative and flexible workforce that will enable the nation state to compete successfully in the global market. Such arguments have so often appeared in the EU and some other international documents, as well as in the government programmes of many countries, that nowadays they seem almost self-evident. Some decades ago, however, the reasons why politicians decided to reform education were quite different. ${ }^{14}$ Social mobility and the well-being of individuals were much more important at that time. However, these differences only prove that there are different priorities; they do not prove that economic reasons are considered as the only reasons for education reforms today. Equity, social cohesion and active citizenship, for instance, are still cited as goals of education reforms (Council of Europe, 2009,

14 Such a conclusion seems to be at least partly confirmed by the review of education reforms in European countries in the last century. In addition, it also seems that creativity and innovation did not play a significant role in the education reforms of that time, that is, until 2009 (Garrouste, 2010). On the other hand, the 2010 research report on a project that started in December 2008 already shows a shift in the emphasis on creativity and innovation in education in EU countries. This study, for instance, "shows that the terms 'creativity', and 'innovation' and their synonyms are mentioned relatively often in the EU27 curricula". However, "many teachers and education experts ... feel that the curricula in their countries do not, as yet, sufficiently encourage creativity and innovation, mainly because they are not clear how creativity should be defined and how it should be treated in learning and assessment". In addition, "curricula are often overloaded with content, which reduces the possibilities of creative and innovative learning approaches in practice" (Cachia et al., 2010, p. 9). 


\section{p. 3). ${ }^{15}$ What has changed is that among the reasons that politicians and reform-} ers use to justify education reforms, economic reasons are undoubtedly the most important (Levin, 1998, pp. 131-132).

Consequently, the understanding of creativity and innovation has changed, as well. Creativity, for instance, has a long history as both a term and a concept in the fields of European art, philosophy and theology (Tatarkiewicz, 1980, pp. 244-265). ${ }^{16}$ Something similar can also be said for the concept of innovation, whose meaning has changed throughout history and in accordance with its different definitions in scientific, technological, humanistic, economic and managerial literature (Godin, 2008). For the purpose of the present paper, it might be useful to mention that innovation has not always been seen as something good, that is, as a value. ${ }^{17}$ Nowadays, however, creativity and innova-

15 However, the question is whether the stated goals are compatible with each other. Is, for example, "active citizenship" compatible with "entrepreneurship", that is, with the neoliberal conception of man as "human capital" or as a "self-entrepreneur" (cf. Laval, 2018, pp. 55-58), if active citizenship is a characteristic of a political man? Wendy Brown (who extended Foucault's analysis of neoliberalism to the issue of democracy) claims that "as humans become capital for themselves, but also for others, for a firm or a state, their investment value, rather than their productivity, becomes paramount; moral autonomy and hence the basis of sovereign individuality vanishes; and the space and meaning of political citizenship shrink" (Brown, 2015, p. 78). Moreover, one of the consequences of neoliberalism is the replacement of the political man (homo politicus) by the economic man (homo oeconominus). This "neoliberal triumph of homo oeconomicus as the exhaustive figure of the human is undermining democratic practices and a democratic imaginary by vanquishing the subject that governs itself through moral autonomy and governs with others through popular sovereignty. The argument is that economic values have not simply supersaturated the political or become predominant over the political. Rather, a neoliberal iteration of homo oeconomicus is extinguishing the agent, the idiom, and the domains through which democracy - any variety of democracy - materializes" (Ibid., p. 79).

16 The concept of creativity appears "only at the very end of antiquity: specifically, in the sense of fashioning something from nothing. But the initial view of creativity was a negative one; it held that there is no creativity" (Ibid., p. 251) because creation de nihilo, as Lucretius argued, does not exist. In Mediaeval theology, the existence of creativity (understood as creatio ex nihilo) was affirmed by the idea of God as a creator. In the nineteenth century, "the concept of creativity was transformed" radically and "the meaning of the expression changed" because "the requirement 'from nothing' was dropped. Creativity in the altered construction became the making of new things rather than the making of things from nothing" (Ibid.). Although "not every novelty sufficed for creativity", "in the end it was novelty that defined creativity. With the new concept, a new theory arose: creativity was an exclusive attribute of the artist" and "the artist alone is a creator" (Ibid.). However, "in the 2oth the idea has arisen that ... not only artists but persons active in other departments of culture may likewise be creative. Creativity is possible in all fields of human production" because "novelty occurs in works not only of art but likewise of science and technology” (Ibid., p. 254).

17 Just the opposite: "innovation was pejorative for a while. Until the eighteenth century, a "novator" was still a suspicious person, one to be mistrusted. Before the twentieth century, there had been two episodes in history where innovation was opposed. The first was in political and religious matters. Because of tradition, political change was negatively received, and because of orthodoxy, innovation was considered heresy; thereafter innovation was identified with the introduction of anything deviant in political affairs and in the Church. The second episode was during the eighteenth century, when inventors started making money from their inventions. Projectors, as the innovators were then called, became objects of satire by many authors because of insufficient science, bad management and fraud" (Ibid., p. 24). 
tion are seen as very important values. They are predominantly understood as different but interrelated concepts. Creativity is seen as the process of developing and expressing novel ideas, knowledge and practices, while innovation is viewed as the practical implementation of these ideas, knowledge and practices in new products or services that create economic value. Conceived in such a way, creativity is, as previously discussed, a means and not an end. As such, it primarily has an instrumental value: it is valued first and foremost because it is a necessary condition for innovation. However, not only creativity but also innovation has an instrumental value, because it, too, is a means to an end. This is evident from the explanation of innovation as "harnessing creativity for business growth" (Jolly, 2003), as well as from the aforementioned real reason for introducing education reform (which emphasises the enhancement of creativity and innovation in education): "enterprise development and Europe's ability to compete internationally". In the neoliberal context, however, innovation is not only a personal skill and, therefore, something that should be enhanced "at all levels of education and training" in "an environment that is conducive to all forms of ... innovation, whether artistic, cultural, social or technological" - as stated in the previously discussed EU documents - but is, according to Luc Ferry, the essence of neoliberal capitalism, as well. The latter's philosophical reinterpretation of the idea of innovation as a source of capitalism defined as "creative destruction" (Schumpeter, 1942) into a concept of "destructive innovation" reveals the paradoxical nature of the permanent process of innovation, which destroys the present in order to create the future. From this perspective, neoliberal capitalism is seen as something that forces us to submit to the perpetual logic of innovation for the sake of innovation, which not only leads to progress in economic and some other areas, but also to the incessant "rupture with all the forms of heritage, patrimony, and tradition" (Ferry, 2014, p. 14). It is precisely this deconstructive side of the innovation process that seems to be overlooked or deliberately silenced when innovation, along with creativity, is established as the goal of social and education reforms. 


\section{References}

Anscombe, G. E. M. (1963). Intention. Basil Blackwell.

Anscombe, G. E. M. (1989). Von Wright on practical inference. In P. A. Schlipp \& L. E. Hahn (Eds.),

The philosophy of Georg Henrik von Wright. La Salle.

Beardsley, M. C. (1965). Intrinsic value. Philosophy and Phenomenological Research, 26(1), 1-17.

Brown, W. (2015). Undoing the demos: Neoliberalism's stealth revolution. Zone Books.

Cachia, R., Ferrari, A., Ala-Mutka, K., \& Punie, Y. (2010). Creative learning and innovative teaching:

Final report on the study on creativity and innovation in education in the EU member states.

Publications Office of the European Union.

Conference Theme. (2013). Creativity and innovation in educational research. ECER.

Council of Europe. (2009). Council conclusions on a strategic framework for European cooperation in education and training (Education and training 2020). Official Journal C 119, 28. 05. 2009.

Elster, J. (1987). Comment on van der Veen and Van Parijs. Theory and Society, 15(5), 709-721.

EUR LEX. (2006). EUR-Lex-52006DCoo33 (Communication from the Commission to the Council, the European Parliament, the European Economic and Social Committee and the Committee of the Regions - Implementing the Community Lisbon Programme: Fostering entrepreneurial mindsets through education and learning $/{ }^{*} \mathrm{COM} / 2006 / 0033$ final $* /$ ).

EUR LEX. (2008). EUR-Lex-l29020 (Decision No 1350/2008/EC of the European Parliament and of the Council of 16 December 2008 concerning the European Year of Creativity and Innovation (2009)).

Ferry, L. (2014). L'innovation destructrice [Destructive innovation]. Plon.

Frankena, W. K. (1973). Ethics. Prentice-Hall.

Garrouste, C. (2010). 100 years of educational reforms in Europe: A contextual database. Publications Office of the European Union.

Godin, B. (2008). Innovation: The history of a category, project on the intellectual history of innovation working paper No. 1. www.csiic.ca

Jolly, A. (Ed.) (2003). Innovation: Harnessing creativity for business growth. Kogan Page.

Kant, I. (2004). The moral law (Groundwork of the metaphysic of morals). Routledge.

Laval, C. (2018). Foucault, Bourdieu et la question néolibérale [Foucault, Bourdieu and the neoliberal question]. La découverte.

Levin, B. (1998). An epidemic of education policy: (What) can we learn from each other?

Comparative Education, 34(2), 131-141.

MacIntyre, A. (1964). Against utilitarianism. In T. H. B. Hollins (Ed.), Aims in Education. The

Philosophical Approach. Manchester University Press.

Manifesto for creativity and innovation in Europe. (2009). European Commission - IP/o9/1702

12/11/2009. P. 1.

Moore, G. E. (1912). Ethics. Williams and Norgate.

Ross, D. (2002). The right and the good. Clarendon Press. 
Schumpeter, J. A. (1942/1962). Capitalism, socialism and democracy. Harper.

Tatarkiewicz, W. (1980). A history of six ideas: An essay in aesthetics. Nijhoff.

Von Wright, G. H. (1971). Explanation and understanding. Cornell University Press.

White, J. (1982). The aims of education restated. Routledge and Kegan Paul.

Zimmerman, M. J. (2010). Intrinsic vs. extrinsic value. In E. N. Zalta (Ed.), The Stanford

encyclopaedia of philosophy (Winter ed). http://plato.stanford.edu/archives/win2010/entries/valueintrinsic-extrinsic/

\section{Biographical note}

Zdenko Kodelja, PhD both in Philosophy and Education, is a full-time researcher ad Head of the Centre for Philosophy of Education at the Educational Research Institute, Ljubljana, Slovenia. 